\title{
Implementasi Kebijakan Standar Pelayanan Minimal Pendidikan Dasar di Dinas Pendidikan Kabupaten Sleman
}

\author{
Oktaria Vitri, Retno Kusumawiranti, Suwarjo \\ Prodi Administrasi Negara Fakultas Ilmu Sosial dan Ilmu Politik \\ Universitas Widya Mataram \\ retno_zan@yahoo.co.id
}

\begin{abstract}
The aim of this research is to find out and examine the implementation of basic minimum service standard (SPM) policies in the Sleman District Education Office. The type of research is qualitative descriptive research. Data collection techniques used are observation, interviews, and documentation. Analysis of the data with qualitative analysis. The implementation of policies related to the fulfillment of the Basic Education SPM which is the authority of the Sleman Regency Government has not yet reached $100 \%$. In the indicator of basic education quality services from the side of access distance has been fulfilled while the indicators of study groups (rombel) have not been fulfilled. In the indicators of basic education quality services in terms of laboratory availability has not been fulfilled while the availability of teacher rooms already meets SPM standards. In basic education quality services in terms of teacher education qualifications, principals and supervisors have been fulfilled, but in terms of teacher qualifications the educator certified has not been fulfilled. Whereas the indicators for the realization of visits by supervisors to educational units are carried out once every month and each visit is carried out for 3 hours to carry out supervision and guidance not fulfilled. Therefore, in order to fulfill SPM Dikdas, it is best to: give sanctions to schools whose number of classes exceeds SPM, allocate funds with the SPM fulfillment priority scale, provide (support to teachers of PPG trainers) and optimize school supervisor performance.
\end{abstract}

Key words: Implementation of policies, minimum service standards, basic education

\section{Pendahuluan}

Masalah pendidikan merupakan salah satu agenda besar pemerintah baik pusat maupun daerah. Kebijakan pembangunan pendidikan diprioritaskan pada peningkatan akses masyarakat terhadap pendidikan dasar yang lebih berkualitas melalui peningkatan pelaksanaan wajib belajar pendidikan dasar 9 tahun dan pemberian akses yang lebih besar kepada kelompok masyarakat yang selama ini kurang dapat menjangkau layanan pendidikan dasar. Undang-undang Nomor 20 Tahun 2003 tentang Sistem Pendidikan Nasional mengamanatkan bahwa setiap warga negara yang berusia 7-15 tahun wajib mengikuti pendidikan dasar. Konsekuensi dari amanat 
undang-undang tersebut maka pemerintah wajib memberikan layanan pendidikan bagi seluruh peserta didik pada tingkat pendidikan dasar (SD/MI dan SMP/MTs serta satuan pendidikan yang sederajat). Salah satu langkah yang diambil oleh pemerintah pusat untuk meningkatkan mutu dan pelayanan terhadap pendidikan adalah menetapkan indikatorindikator standar pelayanan pendidikan kepada pemerintah kabupaten/kota.

Sesuai dengan Peraturan Pemerintah Nomor 38 Tahun 2007, urusan pendidikan merupakan salah satu pelayanan wajib yang harus diselenggarakan oleh pemerintah kabupaten/kota. Lebih lanjut Undang-Undang Nomor 32 Tahun 2004 menyatakan bahwa penyelenggaraan pelayanan wajib yang didesentralisasikan perlu diatur dalam Standar Pelayanan Minimal (SPM). Sesuai dengan Peraturan Pemerintah Nomor 65 Tahun 2005, SPM adalah ketentuan mengenai jenis dan mutu pelayanan dasar yang merupakan urusan wajib daerah yang berhak diperoleh setiap warga negara secara minimal, terutama yang berkaitan dengan pelayanan dasar.

Standar Pelayanan Minimal disusun sebagai alat pemerintah dan pemerintahan daerah (Pemda) untuk menjamin akses dan mutu pelayanan dasar kepada masyarakat secara merata dan sebagai patokan pelayanan minimal yang wajib dilakukan oleh pemerintah kabupaten/kota dalam penyelenggaraan pendidikan sehingga dengan adanya standar pelayanan minimal diharapkan tercapainya tujuan pendidikan nasional seperti yang tertuang dalam UUD 1945 yaitu mencerdaskan kehidupan bangsa serta ikut melaksanakan ketertiban dunia yang berdasarkan kemerdekaan, perdamaian abadi dan keadilan sosial. Model Standar Pelayanan Minimal ini, menjadi hal yang perlu diperhatikan mengingat aspek-aspek yang diujikan dapat dijadikan pedoman yang sangat penting bagi penyelenggaraan pendidikan. Sehingga apabila dari Standar Pelayanan Minimal sudah bisa berjalan beriringan dengan managemendan inovasi pendidikan yang lainnya. Maka tak dipungkiri keterkaitan satu dengan yang lain menjadi patut untuk diteliti. Agar bisa menjadi salah satu fondasi terhadap pengembangan model program pendidikan formal yang selanjutnya bisa lebih baik dan menunjang bagi terselenggaranya program pendidikan formal yang efektif dan efisien serta memiliki mutu yang bersaing dengan pendidikan formal lainya.

$$
\text { Permendikbud Nomor } 23 \text { Tahun }
$$

2013 (beserta lampirannya) memuat penjelasan secara rinci mengenai pengertian, metoda pengukuran indikator, analisis kebutuhan biaya pemenuhan SPM, dan langkah-langkah untuk menuangkannya ke dalam dokumen perencanaan daerah. Sebagaimana tertuang dalam Permendikbud tersebut terdapat 27 indikator SPM Dikdas. Dari 27 indikator layanan tersebut 14 indikator menjadi kewenangan kabupaten/kota dalam hal ini adalah Dinas Pendidikan selaku pemangku kepentingan dan 13 indikator menjadi kewenangan Satuan Pendidikan Dasar (SD, SMP, MI\& MTs). Dalam hal ini penelitian akan difokuskan pada 14 indikator yang menjadi kewenangan kabupaten/kota yaitu kewenangan pemerintah daerah dalam 
Oktaria Vitri, Retno Kusumawiranti, Suwarjo, Implementasi Kebijakan Standar ...

hal ini adalah Dinas Pendidikan Kabupaten Sleman selaku pemangku kepentingan karena dari 14 indikator tersebut ada 5 indikator yang belum memenuhi Standar Pelayanan Minimal (SPM) berdasarkan sensus SPM tahun 2017. Berdasarkan hasil sensus capaian SPM Dikdas tahun 2017 dapat disimpulkan bahwa masih terdapat indikator-indikator SPM Dikdas yang belum mencapai 100\%. Dari 14 indikator SPM Dikdas yang menjadi kewenangan pemerintah Kabupaten Sleman terdapat 4 indikator yang telah mencapai $100 \%, 5$ indikator yang mencapai 93\% keatas dan 5 indikator yang masih berkisar 76-87 \%.

Berdasarkan prasurvey peneliti kepada Dinas Pendidikan Kabupaten Sleman sampai dengan saat ini masih terjadi kesenjangan mutu pelayanan pendidikan dasar antar kabupaten/kota, antar sekolah dengan sekolah dan antar sekolah dengan madrasah. Misalnya banyak sekolah yang jumlah setiap rombongan belajar setiap kelasnya lebih dari 32 siswa untuk jenjang SD/MI dan lebih dari 36 siswa untuk SMP/MTs. Dari sesi sarana dan prasara beberapa sekolah juga belum memenuhi SPM karena beberapa peralatan laboratorium, meja kursi siswa sudah banyak yang rusak. Untuk tenaga pendidik sampai dengan saat ini masih banyak tenaga pendidik yang belum mempunyai sertifikat pendidik.

\section{Tinjauan pustaka}

\section{Implementasi Kebijakan}

Proses implementasi menjadi bagian yang penting untuk mengetahui kinerja implementasi. Kinerja implementasi kebijakan secara sederhana menggambarkan tingkat pencapaian tujuan kebijakan, yaitu apakah hasil-hasil kebijakan (policy outcomes) yang diperoleh melalui serangkaian proses implementasi tersebut secara nyata mampu mewujudkan tujuan kebijakan yang telah ditetapkan (policy goal). Derajat kinerja implementasi kebijakan dengan demikian menggambarkan berbagai variasi perbandingan terbaik antara policy outcomes dengan policy goals. Semakin tinggi policy outcomes maka semakin tinggi pula kinerja implementasi kebijakan yang berhasil diraih oleh suatu kebijakan (Purwanto dan Sulistyastuti, 2012:66-67). Merujuk pada pendapat Ripley (1985:34) dalam Purwanto dan Sulistyastuti (2012 : 68-69), implementasi dapat dilihat dari 2 (dua) perspektif sebagaimana ia jelaskan:

"Implementation studies have two major foci: "complience" and "what's happening?".

Perspektif pertama (complience perspective) memahami keberhasilan implementasi dalam arti sempit yaitu sebagai kepatuhan para implementer dalam melaksanakan kebijakan yang tertuang dalam dokumen kebijakan. Melalui cara pandang yang demikian studi implementasi yang menggunakan perspektif ini juga ingin mengetahui kepatuhan para bawahan dalam menjalankan perintah yang diberikan oleh atasan sebagai upaya menjalankan perintah suatu kebijakan.

Dari perspektif kepatuhan tersebut boleh dikatakan sangat kental dipengaruhi oleh pandangan yang melihat keberhasilan 
Jurnal Populika, Volume 7, Nomer 1, Januari 2019

implementasi ditentukan oleh persoalan pengelolaan urusan administrasi dan manajemen. "Keberhasilan implementasi secara mudah dapat dilihat melalui serangkaian checklist tentang apa yang harus dilakukan oleh para implementer dalam melakukan delivery berbagai policy output kepada kelompok sasaran" (Purwanto dan Sulistyatuti, 2012:69). Policyoutput merupakan instrumen kebijakan untuk dapat mewujudkantujuan-tujuan kebijakan yang telah ditetapkan.

Pada perspektif kedua berusaha untuk memahami implementasi secara lebih luas. Ripley (1985:134) dalam Purwanto dan Sulistyastuti (2012: 69-70) mengukur keberhasilan implementasi melalui pertanyaan "What is it achieving? And Why or What's happening? and why?". Ukuran keberhasilan implementasi tidak hanya dilihat dari segi kepatuhan para implementer dalam mengikuti SOP namun demikian juga diukur dari keberhasilan mereka dalam merealisasikan tujuan-tujuan kebijakan yang wujud nyatanya berupa munculnya dampak kebijakan. Pencapaian tujuan kebijakan sangat dipengaruhi oleh faktor yang lain seperti ketepatan instrumen kebijakan, kecukupan keluaran kebijakan, kualitas keluaran kebijakan, dan lain-lain.

Menurut Pressman dan Wildavsky, implementasi dimaknai dengan beberapa kata kunci yaitu untuk menjalankan kebijakan, untuk memenuhi janji-janji sebagaimana dinyatakan dalam dokumen kebijakan, untuk menghasilkan output dalam tujuan kebijakan, dan untuk menyelesaikan misi yang harus diwujudkan dalam suatu kebijakan (Purwanto dan Sulistyastuti, 2012:20).

$$
\text { Gordon (1986) dalam Keban }
$$

(2015:76-77) berpendapat bahwa implementasi berkenaan dengan berbagai kegiatan yang diarahkan pada realisasi program. Dalam hal ini, administrator mengatur cara untuk mengorganisir, menginterpretasikan dan menerapkan kebijakan yang telah diseleksi. Implementasi kebijakan dibutuhkan untuk melihat kepatuhan kelompok sasaran kebijakan. Dilihat dari perspektif perilaku, kepatuhan kelompok sasaran merupakan faktor penting yang menentukan keberhasilan implementasi kebijakan. Pemikiran ini sejalan dengan pandangan Ripley dan Franklin (1986:12) dalam Akib (2010:3) bahwa untuk mendukung keberhasilan implementasi kebijakan perlu didasarkan pada tiga aspek, yaitu: 1) tingkat kepatuhan birokrasi terhadap birokrasi di atasnya atau tingkatan birokrasi, sebagaimana diatur dalam undang-undang, 2) adanya kelancaran rutinitas dan tidak adanya masalah; serta 3) pelaksanaan dan dampak (manfaat) yang dikehendaki dari semua program terarah.

\section{Standar Pelayanan Minimal Pendidikan Dasar}

Menurut Peraturan Menteri Pendidikan Nasional Republik Indonesia Nomor 15 Tahun 2010, Standar Pelayanan Minimal Pendidikan Dasar atau SPM Pendidikan adalah tolok ukur kinerja pelayanan pendidikan dasar melalui jalur pendidikan formal yang diselenggarakan oleh 
kabupaten/kota. Sesuai dengan Peraturan Pemerintah Nomor 38 Tahun 2007, urusan pendidikan merupakan salah satu pelayanan wajib yang harus diselenggarakan oleh pemerintah kabupaten/kota. Oleh karena itu, Penyelenggaraan Standar Pelayanan Pendidikan Dasar adalah kewenangan kabupaten/kota. SPM pendidikan ini merupakan acuan dalam perencanaan program dan penganggaran pencapaian target baik tingkat satuan pendidikan maupun tingkat kabupaten/kota Penerapan. SPM Pendidikan ini bertujuan untuk menjamin akses dan mutu bagi masyarakat untuk mendapatkan pelayanan dasar dari pemerintah kabupaten/kota sesuai dengan ukuran-ukuran yang telah ditetapkan oleh pemerintah.

Sesuai dengan Peraturan Menteri Pendidikan dan Kebudayaan Republik Indonesia Nomor 23 Tahun 2013, dalam penyelenggaraan SPM Pendidikan terdapat berbagai indikator yang terbagi menjadi 2 kelompok indikator yaitu penyelenggaraan pendidikan dasar oleh kabupaten/kota dan penyelenggaraan pendidikan dasar oleh satuan pendidikan. Sesuai dengan sasaran dalam Rencana Pembangunan Jangka Menengah Nasional Tahun 2010-2014 Bidang Sosial Budaya dan Kehidupan Beragama, SPM Pendidikan Dasar harus telah tercapai 100 persen. Oleh karena itu seluruh sekolah SD hingga SMP di Indonesia harus telah memenuhi kualifikasi dalam SPM.

Dalam Undang-undang No.20 Tahun 2003 pasal 17 ayat (1) bahwa pendidikan dasar merupakan jenjang pendidikan yang melandasi jenjang pendidikan menengah. Sedangkan pada ayat (2) menyebutkan bahwa pendidikan dasar berbentuk Sekolah Dasar (SD) dan Madrasah Ibtidaiyah (MI) atau bentuk lain yang sederajat serta sekolah menengah pertama (SMP) dan Madrasah Tsanawiyah (MTS), atau bentuk lain yang sederajat.

\section{Metode penelitian}

Dalam penelitian ini, peneliti menggunakan metode penelitian kualitatif. Metode kualitatif berusaha memahami dan menafsirkan makna suatu peristiwa interaksi tingkah laku manusia dalam situasi tertentu menurut persepektif peneliti sendiri. Penelitian ini digolongkan dalam penelitian deskriptif. Format penelitian deskriptif bertujuan untuk menggambarkan, meringkaskan berbagai kondisi, berbagai situasi atau berbagai variabel yang timbul di masyarakat yang menjadi objek penelitian itu (Bungin, 2013 : 48). Teknik pengumpulan datanya dengan cara observasi, wawancara dan dokumentasi. Adapun informan yang ditunjuk dalam penelitian ini antara lain: Sekretaris Dinas Pendidikan Kabupaten Sleman, Kepala Bidang Pembinaan SD Dinas Pendidikan, Kepala Subagian Perencanaan dan Evaluasi Dinas Pendidikan Kabupaten Sleman, Kepala Seksi Kesiswaan SMP Dinas Pendidikan Kabupaten Sleman, Pengawas Madya jenjang SD dan SMP, dan 2 Kepala Sekolah SD dan SMP.

\section{Pembahasan}

$\begin{array}{lcr} & \text { Sebagaimana tertuang } & \text { dalam } \\ \text { peraturan } & \text { perundang-undangan } & \text { bahwa } \\ \text { kewenangan } & \text { bidang pendidikan } & \text { telah }\end{array}$


diserahkan atau didesentralisasikan pada daerah, maka pemerintah pusat mewajibkan daerah untuk menyelenggarakan layanan pendidikan sesuai dengan standar pelayanan minimal. Standar pelayanan minimal pendidikan dasar di Kabupaten Sleman intens diimplementasikan pada tahun 2014, setelah pemerintah Kabupaten Sleman mendapatkan pendampingan dalam penerapan standar pelayanan minimal pendidikan dasar dari pemerinatah pusat.

Terdapat 27 indikator standar pelayanan minimal pendidikan dasar yang harus dipenuhi oleh seluruh satuan pendidikan, namun untuk pemenuhannya terbagi atas 2 kelompok tanggungjawab pemenuhan. Untuk indikator 1 sampai dengan 14, pemenuhannya menjadi tanggungjawab pemerintah daerah yang didanai dengan dana APBD (Anggaran Pendapatan dan Belanja Daerah), DAU (Dana Alokasi Umum), DAK (Dana Alokasi Khusus), PAD (Pendapatan Asli Daerah) dan lain-lain. Sedangkan untuk indikator 15 sampai dengan indikator 27 pemenuhannya menjadi tanggungjawab sekolah yang didanai dengan dana BOS, dana Komite Sekolah, atau sumber pendanaan lainya. Dalam kurun waktu Tahun 2014 sampai dengan Tahun 2018, capaian SPM di Kabupaten Sleman telah mengalami peningkatan, namun belum bisa memenuhi secara keseluruhan. Dari hasil monitoring dan pendataan sensus 2018 dan Dokumen Roadmap Tahun 2017 terkait dengan pemenuhan SPM Dikdas disampaikan bahwa:

\section{A. Pelayanan mutu pendidikan dasar dari sisi akses jarak jangkau dan rombongan belajar (rombel).}

Berdasarkan Dokumen roadmap SPM Dikdas 2017 Pemerintah Kabupaten Sleman telah berhasil memberikan layanan pendidikan dasar di wilayahnya secara maksimal. Pemerintah telah membangun satuan pendidikan baik itu SD/MI maupun SMP/MTs secara merata ke seluruh daerah Kabupaten Sleman. Hal ini berarti masyarakat dapat memperoleh layanan pendidikan dasar secara efisien dan efektif karena jarak tempuh dari rumah tinggal ke satuan pendidikan tidak lebih dari $3 \mathrm{~km}$ untuk jenjang SD/MI dan 6 $\mathrm{km}$ untuk jenjang SMP/MTs. Pemenuhan standar ini disebabkan karena Pemerintah Kabupaten Sleman dalam Penerimaan Peserta Didik Baru (PPDB) telah mengeluarkan kebijakan zonasi bagi satuan pendidikan baik itu jenjang SD/MI maupun SMP/MTs. Untuk jenjang SD/MI pembagian zonasi berdasarkan padukuhan wilayah sekitar, sedangkan untuk jenjang SMP/MTs berdasarkan zona wilayah kecamatan yang terbagi menjadi 4 zonasi yaitu Zona Barat, Zona Tengah, Zona Utara dan Zona Timur.

Dari hasil sensus 2018 dari jumlah sekolah yang yang melebihi rombongan belajar (rombel) sebagian besar sekolah swasta yang berbasis sekolah yayasan. Hal ini disebabkan karena untuk sekolah swasta terutama sekolah yayasan kebijakan dari Pemerintah Kabupaten Sleman terutama Dinas Pendidikan memperbolehkan sekolah yayasan tersebut boleh memungut biaya pendidikan dari siswa didiknya dan tidak ada regulasi 
yang mengatur jumlah besaran biayanya. Jadi sebagian sekolah swasta berusaha mencari siswa didik sebesar-besarnya sebagai sumber dana dalam operasional sekolah tentunya disesuaikan dengan output/keluaran mutu sekolah tersebut.

Berdasarkan data jumlah satuan pendidikan di Dinas Pendidikan Kabupaten Sleman diketahui juga bahwa di wilayah Kabupaten Sleman jumlah satuan pendidikan jenjang SMP/MTs di tahun 2018 mengalami perubahan yaitu dari jumlah 110 menjadi 113 sekolah. Hal ini juga merupakan salah satu alternatif kebijakan dalam pemenuhan SPM karena sebelumnya di tahun 2017 ada 16 sekolah jenjang SMP/MTs yang rombongan belajarnya melebihi dari 36 orang.

\section{B. Tercapai tidaknya pelayanan mutu} pendidikan dasar dari sisi ketersediaan laboratorium dan ruang guru.

Pemenuhan SPM Dikdas di setiap SD/MI dan SMP/MTs tersedia satu ruang guru yang dilengkapi dengan meja dan kursi untuk setiap orang guru, kepala sekolah dan staf kependidikan lainnya; dan di setiap SMP/MTs tersedia ruang kepala sekolah yang terpisah dari ruang guru. Pada sub indikator pelayanan ini, jumlah SMP/MTs yang memiliki ruang laboratorium IPA yang dilengkapi dengan meja dan kursi untuk 36 peserta didik sebesar $83,78 \%$ beserta jumlah SMP/MTs yang memiliki satu set peralatan praktek IPA untuk demonstrasi dan eksperimen peserta didik di Kabupaten Sleman sampai saat ini bisa dikatakan masih rendah. Jumlah SMP/MTs di Kabupaten Sleman yang telah mencapai SPM untuk sub ini 95 sekolah dan yang belum mencapai SPM 18 sekolah yang belum memiliki ruang laboratorium IPA yang dilengkapi dengan meja dan kursi untuk 36 peserta didik. Dari 18 sekolah tersebut adalah terdiri dari sekolah baru dan sekolah yayasan. Untuk sekolah negeri semuanya sudah memenuhi SPM. Berdasarkan DPA (Dokumen Pelaksanaan Anggaran) yang di sampaikan Kepala Seksi Sarana dan Prasaran SMP terkait dengan pelayanan mutu pendidikan dasar dari sisi ketersediaan laboratorium jenjang SMP Dinas Pendikan telah mengalokasikan dana dalam pemenuhan SPM yaitu sebesar 28 paket untuk laboratorium komputer dari DAK dan 1 paket untuk laboratorium IPA serta pengadaan komputer PC Server sebesar 25 paket. Selain itu Dinas Pendidikan juga mengalokasikan dana untuk pengadaan peralatan pendidikan untuk jenjang SD dan SMP.

Dari hasil sensus 2018 capaian Sub I.P 4.3 sudah mencapai $100 \%$, artinya dari jumlah SMP/MTs sejumlah 113 semuanya sudah memiliki ruang kepala sekolah/madrasah yang terpisah dengan ruang guru dan dilengkapi dengan meja kursi.Sedangkan untuk SD/MI masih belum mencapai target yang diwajibkan. Dari hasil sensus Tahun 2018 diketahui bahwa capaian Sub 4.1 sebesar $88,95 \%$ meningkat dari tahun lalu yang hanya $84,41 \%$ masih terdapat 56 sekolah yang belum memiliki ruang guru, meja, serta kursi pendidik dan tenaga kependidikan. Dari jumlah SD/MI di Kabupaten Sleman 507 sekolah yang sudah memenuhi SPM Dikdas untuk Sub I.P 4.1 ini sebesar 451 sekolah. 


\section{Tercapai tidaknya pelayanan mutu pendidikan dasar dari sisi kualifikasi pendidikan guru, kepala sekolah dan pengawas.}

Berdasarkan sensus 2018 diketahui bahwa dari 507 satuan pendidik semua gurunya sebagian besar sudah memenuhi kualifikasi akademik S1 ataupun DIV dan hanya 16 satuan pendidik yang jumlah SD/MI memiliki 2 orang guru yang telah memiliki sertifikat pendidik.Sedangkan untuk jenjang SMP/MTs masih ditemukan 26 satuan pendidik dari 113 SMP/MTs di Kabupaten Sleman yang belum memiliki guru dengan kualifikasi S1 atau DIV $\geq 70 \%$ dan telah memiliki sertifikat pendidik $\geq 35 \%$. Jadi hanya 87 SMP/MTs yang sudah memiliki guru dengan kualifikasi S1 atau DIV dan telah memiliki sertifikat pendidik $\geq 35 \%$.

Terkait dengan layanan indikator ini Pemerintah Kabupaten Sleman di tahun 2017 Dinas Pendidikan telah melakukan PPG (Pendidikan Profesi Guru) sebanyak 341 guru dan yang lolos dan siap terima SK 198 guru. Kemudian di tahun 2018, Dinas Pendidikan juga bekerja sama dengan Kementerian Pendidikan dan Kebudayaan RI telah menyiapkan kuota sebesar 280 peserta PPG. Bagi yang tidak lolos PPG akan diadakan tes Ujian Tes Nasional PPG 2018 (UTN).

Berikut ini kami sampaikan tabel data laporan kelulusan sertifikasi tahun 2017.

\section{Tabel 1}

\section{Data Peserta PPG 2017}

\begin{tabular}{|c|c|c|c|c|}
\hline \multirow{2}{*}{ No } & Jenjang/Status & \multicolumn{2}{|c|}{ Status Kelulusan sertifikasi } & Jumlah \\
\cline { 2 - 4 } & & Lulus & Tidak Lulus & \\
\hline \multirow{4}{*}{1} & TK & 61 & 56 & 117 \\
\cline { 2 - 5 } & Non PNS & 59 & 56 & 115 \\
\cline { 2 - 5 } & PNS & 2 & 0 & 2 \\
\hline \multirow{4}{*}{3} & SD & 112 & 73 & 185 \\
\cline { 2 - 5 } & Non PNS & 28 & 37 & 65 \\
\cline { 2 - 5 } & PNS & 84 & 36 & 120 \\
\cline { 2 - 5 } & SMP & 25 & 14 & 39 \\
\cline { 2 - 5 } & Non PNS & 10 & 13 & 23 \\
\hline Jumlah & PNS & 15 & 1 & 16 \\
\cline { 2 - 5 } & Pon PNS & 97 & 37 & 138 \\
\cline { 2 - 5 } & Total & 198 & 143 & 341 \\
\hline
\end{tabular}

Sumber : Data Hasil Kelulusan PPG 2017 
Oktaria Vitri, Retno Kusumawiranti, Suwarjo, Implementasi Kebijakan Standar ...

Untuk Jumlah SMP/MTs yang memiliki guru dengan kualifikasi akademik S1 atau D-IV dan telah memiliki sertifikat pendidik, masing-masing 1 (satu) orang untuk mapel Matematika, IPA, Bahasa Indonesia, Bahasa Inggris dan PKn di Kabupaten Sleman sampai saat ini belum mencapai target yang telah dicapai yaitu baru sebesar 90,27\% artinya baru 102 sekolah yang telah memenuhi dan masih kurang 11 satuan pendidikan dari 113 satuan pendidikan yang ada di wilayah Kabupaten Sleman. Berdasarkan sensus yang dilakukan di satuan pendidikan hal ini disebabkan oleh banyaknya guru yang sudah purna tugas.

Jumlah Kepala SD/MI yang berkualifikasi akademik S-1 atau D-IV dan telah bersertifikat pendidik hampir memenuhi target yang di wajibkan yaiu mencapai 98,62 $\%$ artinya hanya kurang 7 satuan pendidikan yang kepala sekolahnya berkualifikasi akademik S-1 atau D-IV dan telah memiliki sertifikat pendidik, yakni sekolah yayasan dan sekolah swasta. Begitu pula pada jenjang SMP/MTs, jumlah kepala sekolah yang berkualifikasi akademik S-1 atau D-IV dan telah memiliki sertifikat pendidik sebesar 96,90\% yaitu dari 113 jumlah satuan pendidikan yang ada di Kabupaten Sleman ada 3 satuan pendidikan yang belum memenuhi target SPM Dikdas, itupun terjadi pada sekolah swasta sedangkan di sekolah negeri semua Kepala SMP/MTs nya sudah memenuhi kualifikasi S1 dan telah memiliki sertifikat pendidik.

Jumlah pengawas sekolah/madrasah yang berkualifikasi akademik S-1 atau D-IV dan telah bersertifikat pendidik baik itu jenjang SD/MI maupun SMP/MTs sebesar $100 \%$.

Tabel 2.

Data Rekapan Jumlah Pengawas Kabupaten Sleman

\begin{tabular}{|l|l|l|c|c|c|c|}
\hline \multirow{2}{*}{ No } & \multirow{2}{*}{$\begin{array}{c}\text { Jenjang } \\
\text { Kepngawas }\end{array}$} & \multicolumn{1}{|c|}{$\begin{array}{c}\text { Status } \\
\text { Kepegawaian }\end{array}$} & \multicolumn{2}{|c|}{$\begin{array}{c}\text { Jumah Berertifikat } \\
\text { Pendidik }\end{array}$} & \multicolumn{2}{|l|}{ Kualifikasi Pendidikan } \\
\cline { 4 - 7 } & & $\begin{array}{c}\text { Belum } \\
\text { Memiliki }\end{array}$ & $\begin{array}{c}\text { Sudah } \\
\text { Memiliki }\end{array}$ & S 1 & S 2 \\
\hline 1 & Jenjang SD & PNS & - & 34 & 28 & 6 \\
\hline 2 & $\begin{array}{l}\text { Jenjang } \\
\text { SMP }\end{array}$ & PNS & - & 10 & 4 & 6 \\
\hline
\end{tabular}

Sumber: Dokumen Simpeg 2019 


\section{Realisasi kunjungan pengawas ke satuan pendidikan dilakukan satu kali setiap bulan dan setiap kunjungan dilakukan selama 3 jam untuk melakukan supervisi dan pembinaan.}

Kunjungan pengawas ke satuan pendidikan dilakukan satu kali setiap bulan dan setiap kunjungan dilakukan selama 3 jam untuk melakukan supervisi dan pembinaan. Dari jumlah SD/ MI di Kabupaten Sleman capaian ini sebesar 90,53\% dari 507 satuan pendidikan yang memenuhi hanya 459 sekolah dan yang tidak memenuhi ada 48 satuan pendidik. Jumlah SMP/MTs di Kabupaten Sleman dari 100\% menurun menjadi $97,35 \%$ ada 3 sekolah dari 113 satuan pendidik jenjang SMP/MTs yang belum memenuhi indikator ini.

\section{Kesimpulan}

Berdasarkan pembahasan yang telah di paparkan dapat disimpulkan sebagai berikut:

1. Pada capaian standar pelayanan mutu terkait dengan akses jarak jangkau bisa terpenuhi karena adanya kebijakan zonasi dalam Penerimaan Peserta Didik Baru (PPDB). Sedangkan pada indikator jumlah rombongan belajar belum memenuhi standar karena masih ada sekolah yang jumlahnya melebihi standar SPM.

2. Pada capaian standar pelayanan mutu pendidikan dasar dari sisi ketersediaan laboratorium dan ruang guru ini belum sepenuhnya terpenuhi karena di sekolah-sekolah swasta pada umumnya ketersediaan ruang guru dan laboratorium masih belum maksimal, hal ini terkait dengan adanya larangan pungutan dari satuan pendidikan dan keterbatasan anggaran dari pemerintah.

3. Pada capaian standar pelayananmutu pendidikan dasar dari sisi kualifikasi pendiikan guru, kepala sekolah dan pengawas, yang terkait dengan sisi kualifikasi pendidikan guru berijasah S1 sudah terpenuhi hampir $100 \%$ hanya beberapa guru yang belum berijasah S1 karena baru menyelesaikan studinya. Sedangkan untuk kepala sekolah dan pengawas terkait dengan kualifikasi pendidikan sudah $100 \%$ karena persyaratan untuk menjadi kepala sekolah dan pengawas haruslah bersertifikat pendidik dan berijasah SI linier dengan ketugasnnya. Sedangkan dari sisi guru yang bersertifikat pendidik belum terpenuhi semua karena kuota pelaksanaan Pendidikan Profesi Guru (PPG) dibatasi oleh Pemerintah Pusat dan yang sudah melaksanakan PPG banyak tidak lulus sehingga harus mengulang Ujian Tulis Nasional (UTN). Hal ini menyebabkan daftar peserta yang bersertifikat pendidik tidak sesuai dengan harapan Dinas Pendidikan. 
4. Realisasi kunjungan pengawas ke satuan pendidikan dilakukan satu kali setiap bulan dan setiap kunjungan dilakukan selama 3 jam untuk melakukan supervisi dan pembinaan, terjadi penurunan target dari tahun 2017, terutama pengawas jenjang sekolah dasar karena rasio jumlah pengawas dan sekolah binaannya tidak sesuai. Sedangkan untuk jenjang SMP realisasi kunjungan pengawas sangat minim. Ditemukan sekolah pelaksanaan kunjungannya tidak 3 jam dalam kurun waktu satu bulan bahkan ada sekolah yang tidak dikunjungi selama 4 bulan berturut turut.

\section{Saran}

Saran yang dapat diberikan peneliti agar supaya dapat lebih optimal dan meningkatkan proses pemenuhan Standar Pelayanan Minimal Pendidikan Dasar di Kabupaten Sleman adalah:

1. Memberikan sanksi kepada sekolahsekolah yang kuota rombongan belajar peserta didik melebihi SPM Dikdas. Setiap rombongan belajar tidak boleh melebihi 32 siswa untuk jenjang SD dan 36 untuk jenjang SMP demi kenyamanan belajar peserta didik.

2. Mengalokasikan dana anggaran yang lebih optimal dengan skala prioritas dalam pemenuhan SPM Dikdas. Jadi penganggarannya terfokus pada pemenuhan SPM terutama terkait pada

pembangunan laboratorium dan perangkatnya, mebelair (meja, kursi, papan tulis) dan ruang belajar lain.

3. Memberikan support/dukungan pada guru-guru peserta PPG (Pendidikan Profesi Guru) agar semuanya bisa lulus sehingga kuota dari pemerintah pusat terpenuhi dan bertambahnya guru yang memiliki sertifikat pendidik sehingga pemenuhan SPM dapat terpenuhi.

4. Mengoptimalkan kinerja pengawas meskipun jumlah pengawas tidak rasio dengan sekolah binaannya untuk jenjang SD. Sedangkan untuk jenjang SMP perlu dilakukan monitoring dari pihak Subbagian Kepegawaian terkait ada beberapa sekolah yang tidak pernah dikunjungi oleh pengawas.

\section{Daftar pustaka}

Bafadal, Ibrahim., 2003. Manajemen Perlengkapan Sekolah (Teori dan Aplikasinya).,Bumi Aksara, Jakarta.

Badan Perencanaan dan Pembangunan Nasional. (2012). Laporan akhir kajian kapasitas daerah dalam pelaksanaan standar pelayanan minimal (spm). Jakarta: Direktorat Otonomi Daerah Deputi Bidang Pengembangan Regional dan Otonomi Daerah.

Moleong, Lexi J. 2006. Metodologi Penelitian

Kualitatif. Bandung: PT Remaja Rosdakarya. 
Purwanto, E. Agus dan Sulistyastuti Ratih Sulistyastuti. 2012. Implementasi Kebijakan Publik. Konsep dan Aplikasinya Di Indonesia. Yogyakarta : GavaMedia.

Subarsono. 2009.Analisis Kebijakan

Publik. Konsep,Teori dan Aplikasi.Yogyakarta : Pustaka Pelajar.

Wahab, S. Abdul. 2016. Analisis Kebijakan, Dari Formulasi Ke PenyusunanModelModel Implementasi Kebijakan Publik. Cetakan Kelima. Jakarta : BumiAksara.

Winarno, Budi. 2007. Teori dan Proses Kebijakan Publik (Edisi Revisi). Yogyakarta : Media Pressindo.

\section{Peraturan Perundang-undangan :}

- Undang-undang Nomor 20 Tahun 2003 tentang Sistem Pendidikan Nasional

Peraturan Pemerintah Nomor 65 Tahun 2005 Tentang Pedoman Penyusunan Dan Penerapan Standar Pelayanan Minimal

Peraturan Menteri Pendidikan Nasional Nomor 15 Tahun 2010 tentang Standar Pelayanan Minimal Pendidikan Dasar Di Kabupaten/Kotadan Peraturan Menteri Pendidikan dan Kebudayaan Nomor 23 Tahun 2013 Tentang Perubahan Atas Permendiknas Nomor 15 Tahun 2010 Tentang Standar Pelayanan Minimal Pendidikan Dasar di Kabupaten/Kota 